\title{
Demokrasi, Agama dan Masyarakat Madani
}

\author{
M. Dawam Raharjo
}

\begin{abstract}
As a worldwide actual issue, nowadays, the consept of civil society has been popular in a lot of countries, especially in Asia, in Latin America Military regimes, and in Europe. In Indonesia, the discussion of the subject has moved into substansial area involving the form of civil society that can be established. There are least three models of the concept: firstly, civil society is only an interim form, because it may be destructed, and in turn be demobilished by the power. Secondly, because the state is merely a manifestation of the civil society and the function of the state only to serve greedly persons, the state will be destroyed by the proletar revolution. Thirdly, civil society will be used by the hegemony holder, at the same will be used by the hegemony holder, but at the same time it will ethically function to educate people. Nevertheless, whatever the models, it should be an ethical society that progressively achieve a great civilization.
\end{abstract}

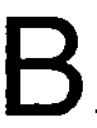

erbagai pemikiran yang dilontarkan akhir-akhir ini di seputar civil society, -yang di Indonesia telah diterjemahkan menjadi "masyarakat sipil" atau "masyarakat madani" itu-, sebenarnya merupakan imbas dari perkembangan pemikiran yang terjadi di dunia Barat, khususnya di negara-negara industri maju di Eropa Barat dan Amerika Serikat, dalam perhatian mereka terhadap perkembangan ekonomi, politik dan sosial-budaya di bekas Uni Soviet dan Eropa Timur. Namun di kawasan bekas Blok Sosialis yang sedang dilanda badai liberalisasi dan demokratisasi itu, berbagai kalangan akademisi juga mulai tertarik untuk membicarakan konsep lama ini. Di Indonesia, -dalam kaitannya dengan konsep masyarakat sipil ini-, kita lebih banyak berbicara mengenai demokratisasi politik atau liberalisasi ekonomi, semacam glasnots dan perestroika seperti yang me- rebak di.Rusia pada dasawarsa '80-an. Konsep masyarakat sipil sendiri di Indonesia adalah sebuah istilah asing atau baru, yang ditanggapi dengan penuh kecurigaan, karena pengertian "sipil" itu dikesankan berkaitan dan tandingan dari "militer", yang dalam masyarakat hadir dalam bentuk dwifungsi ABRl.

Dalam masyarakat Barat, civil society sebenarnya adalah konsep lama yang dilupakan.la mulai bangkit atau diungkap lagi dalam kaitannya dengan perkembangan masyarakat di Eropa Timur di bawah rezim sosialis. Para sarjana di Barat mula-mula melihat konsep itu dalam gejala pergerakan Serikat Buruh Solidaritas yang bangkit melawan negara. Dalam sistem sosialis, kehadiran dan peranan negara sangat kuat. Di mana negara sangat kuat dan mendominasi kehidupan individu dan masyarakat, maka sulit dibayangkan adanya apa yang disebut 
civil society. Tetapi dalam realitas, serikat buruh ternyata cukup kuat dan berperan sebagai masyarakat sipil berhadapan dengan negara. Dan akhirnya, serikat buruh itu ternyata mampu menumbangkan rezim yang begitu kuat. Setelah pemerintahan tumbang, Lech Walensa, pemimpin Serikat Buruh Solidaritas itu, bahkan diangkat menjadi Kepala Negara yang baru.

Dalam teori perjuangan kelas Marx, buruh dan para penganggur akan melakukan pemberontakan melawan dominasi kaum borjuis. Tetapi dalam kasus Polandia, rezim sosialis justru mendapat perlawanan dari kelas buruh. Padahal, rezim sosialis memerintah atas nama kelas buruh dan kaum borjuis dianggap tidak ada.

Menarik untuk diamati bahwa Polandia adalah sebuah negara yang mayoritas penduduknya beragama Katholik yang taat. Tidak kebetulan bahwa Sri Paus yang sekarang menduduki tahta Vatican, adalah seorang rohaniawan yang berasal dari $\mathrm{Po}$ landia. Rupanya, di negara yang sikap pemerintahnya sangat kuat anti-agama itu, agama Katholik ternyata mampu bertahan. Di balik organisasi dan gerakan buruh, berdiri kekuatan sosial gereja. Lebih dari itu, fondasi serikat buruh itu adalah umat beragama yang telah tumbuh menjadi kekuatan rakyat (people's power). Dalam kasus Polandia, sulit kita berbicara mengenai kesadaran kelas (class counsciuosness) pada kaum buruh, karena dalam sistem itu tidak dikenal kelas kapitalis. Yang lebih nampak adalah kesadaran agama yang ternyata mampu mengatasi kesadaran kelas.

Gerakan kemasyarakatan (social movement) adaiah bagian yang esensial dan merupakan pertanda kehadiran masyarakat sipil. Karena itu kita bisa menarik kesimpulan, dalam sistem komunispun, sebuah masyarakat sipil bisa tumbuh, walaupun ia tumbuh sebagai kekuatan reaksi atau anti-tesis terhadap dominasi negara. Pe- merintah yang totaliter itu agaknya memang tidak mampu menemu-kenali tumbuhnya masyarăkat sipil sebagaimana yang dapat dilihat di negara-negara demokrasi-liberal. Serikat buruh, yang diharapkan mendukung pemerintah itu, ternyata justru berkembang menjadi masyarakat sipil. Dalam kasus Polandia, kesadaran sipil itu tumbuh dari masyarakat Katholik yang kuat. Gereja Katholik ternyata juga mampu mengartikulasikan kepentingan dan aspirasi rakyat, dan karena itu menjadi sebuah lembaga dalam masyarakat sipil.

Di Polandia, kita bisa menengok kepada gereja dan umat beragama. Tetapi bagaimana jika kita melihat di negara- negara lain, misalnya di Uni Soviet, Cekoslovakia atau RRC? Apakah peranan Gereja Yunani Ortodoks sama kuatnya dengan $\mathrm{Ge}$ reja Katholik di Polandia? Ternyata proses liberalisasi ekonomi dan demokratisasi politik yang terjadi di Rusia itu cukup kuat juga. Jika yang menggerakkan adalah masyarakat sipil, bagaimana bentuk dan struktur masyarakar sipil itu? Masyarakat Sipil di RRC mungkin lemah atau tidak tampak. Karena itulah maka proses demokratisasi politik di situ mengalami kegagalan, setidak-tidaknya jauh ketinggalan dibanding dengan proses liberalisasi ekonominya.

Dalam kasus Polandia, agama menjadi ibu dari atau paling tidak memangku kelahiran masyarakat sipil. Di negara-negara lain, kedudukan dan peranan agama kurang nampak. Dalam kasus negara sosialis lain, agama justru mengalami marjinalisasi. Namun, masyarakat sipil mungkin pula tumbuh. Pertanyaannya adalah, apakah kehadiran agama membuat perbedaan dalam derajat kekuatan suatu masyarakat sipil?

\section{Arkeologi Konsep}

Secara harfiah, civil society itu sendiri adalah terjemahan dari istilah Latin, civilis 
societas, mula-mula dipakai oleh Cicero (106-43 S.M), -- seorang orator dan pujangga Roma --, yang pengertiannya mengacu kepada gejala budaya perorangan dan masyarakat. Masyarakat sipil disebutnya sebagai sebuah masyarakat politik ( $p o-$ litical society) yang memiliki kode hukum sebagai dasar pengaturan hidup. Adanya hukum yang mengatur pergaulan antar individu menandai keberadaban suatu jenis masyarakat tersendiri. Masyarakat seperti itu, di zaman dahulu adalah masyarakat yang tinggal di kota. Dalam kehidupan kota penghuninya telah menundukkan hidupnya di bawah satu dan lain bentuk hukum sipil (civil law) sebagai dasar dan yang mengatur kehidupan bersama. Bahkan bisa pula dikatakan bahwa proses pembentukan masyarakat sipil itulah yang sesungguhnya membentuk masyarakat kota.

Di zaman modern, istilah itu diambil dan dihidupkan lagi oleh John Locke (16321704) dan Rousseau (1712-1778) untuk mengungkapkan pemikirannya mengenai masyarakat dan politik. Locke umpamanya, mendefinisikan masyarakat sipil sebagai "masyarakat politik" (political society). Pengertian tentang gejala tersebut dihadapkan dengan pengertian tentang gejala "otoritas patemal" (patemal authority) atau "keadalan alami" (state of nature) suatu kelompok manusia. Ciri dari suatu masyarakat sipil, selain terdapatnya tata kehidupan politik yang terikat pada hukum, juga adanya kehidupan ekonomi yang didasarkan pada sistem uang sebagai alat tukar, terjadinya kegiatan tukar menukar atau perdagangan dalam suatu pasar bebas, demikian pula terjadinya perkembangan teknologi yang dipakai untuk mensejahterakan dan memuliakan hidup sebagai ciri dari suatu masyarakat yang telah beradab.

Masyarakat politik itu sendiri, adalah merupakan hasil dari suatu perjanjian kemasyarakatan (social contract), suatu kon- sep yang dikemukakan oleh Rousseau, seorang filsuf sosial Prancis abad ke-18. Dalam perjanjian kemasyarakatan tersebut anggota masyarakat telah menerima suatu pola perhubungan dan pergaulan bersama. Masyarakat seperti ini membedakan diri dari keadaan alami dari suatu masyarakat.

Dalam konsep Locke dan Rousseau belum dikenal pembedaan antara masyarakat sipil dan negara. Karena negara, lebih khusus lagi, pemerintah, adalah merupakan bagian dan salah satu bentuk masyarakat sipil. Bahkan keduanya beranggapan bahwa masyarukat sipil adalah pemerintahan sipil, yang membedakan diri dari masyarakat alami atau keadaan alami.

Pembedaan antara masyarakat sipil dan negara timbul dari pandangan Hegel (1770-1831), pemikir Jerman yang banyak menarik perhatian, yang ditentang dan sekaligus diikuti oleh Marx. Sama halnya dengan Locke dan Rousseau, Hegel melihat masyarakat sipil sebagai wilayah kehidupan orang-orang yang telah meninggalkan kesatuan keluarga dan masuk ke dalam kehidupan ekonomi yang kompetitif. Ini adalah arena, dimana kebutuhan-kebutuhan tertentu atau khusus dan berbagai kepentingan perorangan bersaing, yang menyebabkan perpecahan-perpecahan, sehingga masyarakat sipil itu mengandung potensi besar untuk menghancurkan dirinya. Tapi di sini, masyarakat sipil, tidak sebagaimana halnya pandangan dua pemikir Inggris dan Prancis yang terdahulu, bukanlah masyarakat politik. Yang dipandang sebagai masyarakat politik adalah negara. Oleh $\mathrm{He}-$ gel, masyarakat sipil dihadapkan dengan negara. Agaknya, dari teori Hegel inilah dikenal dikotomi antara negara dan masyarakat (state and society).

Pengertian tentang masyarakat sipil di atas dibalik oleh Hegel dari pandangan Locke dan Rousseau. Baginya, masyarakat 
sipil itu bukan satu-satunya yang dibentuk dalam perjanjian kemasyarakatan (social contract). Dengan perkataan lain, masyarakat sipil adalah satu bagian saja dari tatanan politik (political order) secara keseIuruhan. Bagian dari tatanan politik yang lain adalah negara (state). Di sini, yang dimaksud dengan masyarakat sipil adalah perkumpulan merdeka antara orang seorang yang membentuk apa yang disebutnya burgerlische Gesellschaft atau masyarakat borjuis (bourgeois society).

Hegel dan para pengikutnya membedakan masyarakat sipil dari dan berhadapan dengan negara. Yang pertama adalah bentuk perkumpulan yang bersifat spontan dan berdasarkan kebiasaan dalam masyarakat, tetapi tidak bergantung pada hukum. Sedangkan yang kedua adalah lembaga hukum dan politik yang mengayomi masyarakat secara keseluruhan.

Dari berbagai pandangan di atas, kita bisa pula membedakan antara gejala masyarakat sipil dan masyarakat (society) itu sendiri. Yang pertama adalah perkumpulan-perkumpulan yang mengandung aspek politik. Sedangkan masyarakat merangkum keseluruhan perkumpulan, baik yang terartikulasi secara legal-politis maupun yang tidak, tetapi diayomi, dalam arti diakui kehadirannya dan dilindungi oleh negara. Bahkan prinsip non-intervensi yang meminimalkan peranan negara dalam kehidupan ekonomi, misalnya laissez faire, sebagaimana dikatakan oleh pemikir Marxis Itali, Gramsci, memerlukan legalitas dari atau diciptakan oleh negara sendiri.

Dengan teori Hegel, yang juga mempunyai banyak pengikut, antara lain Marx, walaupun ia juga memelintir teori Hegel yang diikutinya itu, maka kita bisa menggambarkan hasil perjanjian kemasyarakatan itu dari kehidupan alami, dalam bentuk dikotomis, antara masyarakat sipil dengan kehidupan alami di satu pihak dan antara masyarakat sipil dengan negara di lain pihak sebagai berikut:

Para pemikir di atas mendasarkan diri pada teori State of Nature dari John Locke dan Social Contract dari Rousseau. Bedanya, kedua pernikir itu mendefinisikan masyarakat sipil sebagai masyarakat ekonomi maupun politik, sementara itu Hegel, Marx dan Gramsci, menganggap masyarakat sipil semata-mata sebagai masyarakat ekonomi, sementara itu mereka memisahkan masyarakat politik secara sendiri sebagai negara.

Barangkali gambar diatas bisa pula dikonfigurasikan secara vertikal, dimana negara berada di atas, kehidupan alami di bawah, sedangkan masyarakat sipil berada ditengah-tengah sebagai berikut:

Negara
(State)

Masyarakat Sipil
(Civil Society)

Kehidupan Alami (State of Nature)

Untuk lebih jelasnya, masyarakat sipil adalah suatu ruang (realm) partisipasi masyarakat dalam perkumpulan-perkumpulan sukarela (voluntary associations), media massa, perkumpulan profesi, serikat buruh dan tani, gereja atau perkumpulan-perkumpulan keagamaan yang sering juga disebut organisasi massa di Indonesia.

Para filsuf sosial di atas berbeda dalam menilai ruang-ruang kegiatan di atas. Locke, Rousseau dan Adam Smith cen- 
derung untuk mengidealisasikan masyarakat sipil sebagai hasil perkembangan masyarakat pada tahap yang lebih maju yang memiliki kekuatan yang memancar dari dalam dirinya, berupa rasionalitas yang akan menuntun anggota masyarakat ke arah kebaikan umum. Tetapi Hegel mempunyai pandangan yang sebaliknya. Masyarakat sipil mengandung potensi konflik di antara kepentingan-kepentingan individu yang berbeda dan bahkan berbenturan. Bagi Hegel, hanya melalui negara saja, kepentingan-kepentingan umat manusia yang universal bisa terpelihara dan dicapai. Dengan begitu maka Hegel mengidealisasikan negara, sebagai penumbuhan segala nilai kebaikan.

Melalui pandangan ahli hukum Soepomo, anggota Badan Penyelidik Usahausaha Persiapan Kemerdekaan (BPUPKI), kita di Indonesia cenderung mengikuti konsep Negara-Ideal dari Hegel. Dikombinasikan dengan konsep integralistik Muller dan monisme Spinosa, kita memandang negara sebagai penumbuhan nilai-nilai ideal yang terangkum dalam Pancasila. Sebaliknya, kita juga cenderung untuk mencurigai masyarakat sipil. Karena itu maka para pemimpin yang berkuasa selalu cenderung untuk mengintegrasikan masyarakat sipil . ke dalam negara, seperti "Manunggaling Kawulo lan Gust?'

Marx, tampak mengikuti pandangan Hegel, dalam melihat masyarakat sipil sebagai masyarakat borjuis. Bagi Marx, masyarakat borjuis mencerminkan sistem kepemilikan modern yang bermuatan nilai materialisme yang kasar, dimana setiap orang mementingkan diri sendiri (egoism) dan dimana setiap orang berjuang melawan yang lain. Dalam masyarakat borjuis, kedudukan individu paling diutamakan. Sebenarnya, baik Marx maupun Hegel memandang masyarakat sipil sebagai tahap yang jauh lebih maju dalam perkembangan kehi- dupan umat manusia. Sungguhpun begitu, masyarakat sipil mempunyai beberapa ciri negatif seperti, setiap orang memburu kepentingan diri sendiri, serakah, hubungan antar orang yang tidak hangat, karena setiap orang berusaha menjaga keamanan pribadi. Masyarakat sipil semacam ini cenderung untuk bergerak ke arah tata kemasyarakatan yang mengikuti prinsip-prinsipnya sendiri secara mandiri, dan menjauh dari nilai-nilai etis yang dituntut oleh hukum dan perkumpulan politik.

Memandang buruk masyarakat sipil, sebagai masyarakat borjuis tidak berarti Marx mengidealisasikan negara. Bagi Marx, negara tak lain adalah badan pelaksana kepentingan kaum borjuis. Adalah suatu ironi, kata Marx, bahwa negara yang diidealisasikan sebagai wadah nilai-nilai universal, moral dan cita-cita kemasyarakatan, ternyata hanya melayani kepentingan manusia secara parsial, yakni individu- individu yang mengejar kepentingan diri sendiri secara serakah dan terpisah dari kepentingan umum. Oleh sebab itu, maka menurut Marx, negara harus dihapuskan, atau akan diruntuhkan oleh kelas buruh. Ketika negara pada akhimya akan lenyap dengan sendirinya (withering away of the state), maka yang tinggal hanyalah suatu masyarakat tanpa kelas. Visi ini berlawanan dengan visi Hegel, karena di masa depan masyarakat sipillah yang akan runtuh dari dalam, jika negara telah mampu mengayomi seluruh kepentingan masyarakat.

Namun Gramsci, pemula komunismeEropa berkebangsaan Itali itu, punya pandangan yang berbeda, dengan Marx maupun Hegel. Baginya, masyarakat sipil itu bukan semata-mata mewadahi kepentingan individu, tetapi di dalamnya juga terdapat organisasi-organisasi yang berusaha melayani kepentingan orang banyak. Masyarakat sipil juga memiliki potensi untuk bisa mengatur dirinya sendiri secara rasional 
dan mengandung unsur kebebasan.

Gramsci, berbeda dengan Marx yang lebih menekankan adanya saling keterkaitan antara masyarakat sipil dan negara. Memang, masyarakat sipil bisa menjadi benteng dari hegemoni kelas borjuis dan akhirnya menjadi pendukung negara. Tetapi negara juga memiliki fungsi etis, misalnya dalam mendidik masyarakat dan mengarahkan perkembangan ekonomi untuk kepentingan masyarakat. Dalam penglihatannya, negara bisa memiliki berbagai unsur masyarakat sipil.

Dengan demikian kita sebenarnya memiliki tiga visi mengenai masyarakat sipil dan negara. Pertama, kehadiran masyarakat sipil hanya bersifat sementara dalam perkembangan masyarakat. Karena kecenderungannya untuk rusak dari dalam, maka pada akhirnya masyarakat sipil akan ditelan oleh negara, -- yakni sebuah negara ideal -, yang merupakan taraf perkembangan masyarakat yang tertinggi. Kedua, karena negara hanya cerminan saja dari masyarakat sipil dan berfungsi melayani individu yang serakah, maka negara akan diruntuhkan atau runtuh dengan sendirinya dalam suatu revolusi proletar. Jika negara lenyap, maka yang tinggal hanya masyarakat, yakni suatu masyarakat tanpa kelas. Dan ketiga, visi yang melihat bahwa masyarakat sipil tidak saja bisa menjadi benteng kelas yang memegang hegemoni, dalam hal ini kelas borjuasi, tetapi bisa pula menjalankan fungsi etis dalam mendidik masyarakat dan mengarahkan perkembangan ekonomi yang melayani kepentingan masyarakat. Di lain pihak, masyarakat sipil sendiri juga terdiri dari organisasi-organisasi yang melayani kepentingan umum, atau memiliki rasionalitas dan mampu mengatur dirinya sendiri secara bebas. Bisa terjadi keduanya saling mendukung, dalam arti buruk maupun baik dari segi kepentingan umum.

\section{Masyarakat Madani}

Dalam proses terbentuknya masyarakat sipil dan negara modern di Eropa Barat dan Amerika Utara, negara telah disingkirkan dari arena politik dan kenegaraan. Tentang peranan negara itu sendiri banyak timbul kontroversi. Satu versi pandangan mengajukan prinsip non-intervensi dan laissez faire di bidang ekonomi, paling tidak peranan negara yang minimal. Versi yang lain menghendaki peranan negara yang aktif, dalam memelihara kepentingan- kepentingan yang universal (universal interests), mendidik masyarakat, mengarahkan perkembangan ekonomi, melindungi hakhak asasi manusia, membela kepentingan kelompok yang lemah atau bahkan aktif memberdayakan masyarakat, khususnya di kalangan marjinal dalam melakukan partisipasi umum.

Di negara-negara sedang berkembang umumnya, pandangan yang dominan adalah sikap Hegelian terhadap negara. Di satu pihak memandang negara sebagai perwadahan segala sesuatu yang ideal dan dilain pihak kurang percaya kepada masyarakat sipil. Kecenderungan ini, terutama bercermin dari pengalaman Indonesia, dilatar belakangi oleh sejarah kolonialnya.

Di masa kolonial, khususnya menjelang Perang Dunia Kedua, kaum cendekiawan memainkan peranan penting, baik dalam proses pembentukan masyarakat maupun dalam upaya meruntuhkan negara kolonial. Di masa kolonial, proses terbentuknya masyarakat sipil berjalan sangat lambat. Tapi, jika kita melihat masyarakat sipil dari sudut Lockean, Rousseauan dan Smithian, yakni sebagai masyarakat ekonomi dan masyarakat politik sekaligus, maka masyarakat sipil yang bercorak politik lebih cepat berkembang. Di masa kolonial Hindia Belanda, telah tumbuh berbagai jenis perhimpunan sukarela (vo- 
luntary associations), baik yang bercorak budaya, politik, ekonomi dan keagamaan. Pada umumnya berdirinya organisasi-organisasi itu, khususnya menjelang Perang Dunia II, dipelopori oleh kaum cendekiawan.

Boleh dikatakan, kaum cendekiawan bersama-sama dengan ulama, -- yang sering disebut juga cendekiawan tradisional -- , memegang peranan sentral dan mewarnai pembentukan negara. Mereka terpecah pandangannya, dalam melihat kedudukan dan peranan agama dalam negara. Di satu pihak, terdapat pendapat yang menghendaki pemisahan agama dan negara. Dan di lain pihak,-- terutama kelompok Islam --, menentang sekularisme, mengingat kuatnya unsur keagamaan dalam masyarakat, khususnya kaum Muslim, yang pada waktu itu mencakup lebih dari $90 \%$ penduduk.

Konsep negara integralistik yang diajukan oleh Soepomo dan dasar negara Pancasila, adalah sebuah modus kompromi atau mungkin juga sintesa. Dalam modus itu, agama tidak disisihkan peranannya. Tetapi agama, khususnya agama tertentu, dicegah untuk mewarnai hukum dan institusi politik. Sebab, jika suatu agama dinyatakan sebagai dasar negara, maka corak negara akan ditentukan oleh kelompok yang memiliki otoritas keagamaan, yang tak lain adalah ulama.

Dalam konsep negara integralistik, peranan agama-agama diakui dan dilindungi, bahkan diakui untuk dijadikan acuan dan sumber dalam mencari sistem nilai bagi negara. Tetapi nilai-nilai itu oleh perorangan maupun organisasi-organisasi keagamaan harus diperjuangkan dalam suatu proses yang demokratis.

Misi organisasi-organisasi keagamaan adalah menciptakan suatu masyarakat etis. Khusus di lingkungan Islam, corak masyarakat yang diatur oleh hukum (rule of law) sangat ditekankan.Cita "Negara Islam" atau "Masyarakat Islam", menurut Mohammad
Rasyidi, adalah nomokrasi, yakni sebuah negara dan masyarakat yang mengacu kepada norma-norma hukum.

Dalam negara integralistik, nilai-nilai keagamaan dapat dan bebas untuk diperjuangkan. Tetapi wujud hasilnya adalah sebuah hukum nasional. Hanya dalam bidang-bidang tertentu saja, misalnya dalam hukum keluarga, agama Islam diizinkan untuk diberlakukan secara otonom di kalangan umatnya. Tetapi hukum Islam itupun tampil sebagai bagian dari hukum nasional. Akibatnya, timbul kecenderungan untuk menguasai negara atau memperjuangkan nilai-nilai yang dianut oleh suatu kelompok agama melalui negara. Misalnya umat Islam memperjuangkan hukum larangan riba menjadi bagian dari UU Perbankan atau hukum halal-haram ke dalam UU Pangan.

Peranan agama yang kuat seperti di Indonesia, sangat mendukung cita Negara-ldealis. Di sini, negara dipandang sebagai wadah dan sekaligus perwujudan nilainilai luhur yang bersumber pada agama. Itulah yang menjelaskan mengapa di Indonesia, demokrasi diberi predikat Pancasila. Karena demokrasi yang dikehendaki berlaku di Indonesia adalah demokrasi untuk merealisasikan nilai-nilai luhur Pancasila.

Tapi cita ini cenderung juga menelan atau menenggelamkan keberadaan dan peranan masyarakat sipil. Setidak-tidaknya, Negara-Ideal ini cenderung untuk mengintegrasikan masyarakat sipil dengan negara, tetapi berakhir dengan lenyapnya, atau paling tidak marjinalisasi masyarakat sipil.

Dalam kaitan ini, pandangan Gramsci periu diperhatikan. la melihat kehadiran masyarakat sipil bisa bermanfaat atau merugikan negara, dengan perkataan'läin, bisa mendukung atau melawan negara: Bertitik tolak dari pandangan ini, maka perkembangan masyarakat secara positif bisa dilakukan, baik melalui negara maupun ma- 
syarakat sipil. Ini mengharuskan kehadiran masyarakat sipil maupun negara.

Tradisi dalam gerakan Isiam di Indonesia sebenarnya lebih mengacu kepada suatu pembentukan masyarakat. Islam mengacu kepada integrasi umat atau masyarakat (Q.s. Ali Imran: 103). Acuan ke arah integrasi umat ini dipegang terutama oleh Nahdhatul Ulama (NU). Muhammadiyah lebih mengacu kepada penciptaan masyarakat etis yang progresif menuju ke arah keunggulan (Q.s. al Baqarah: 104 dan 110). Tapi dalam pandangan NU maupun Muhammadiyah, peranan negara diperlukan.

Dalam perspektif Islam, civil society lebih mengacu kepada penciptaan peradaban. Kata al din, -- yang umumnya diterjemahkan sebagai agama --, berkaitan dengan makna al tamaddun, atau peradaban. Keduanya menyatu ke dalam pengertian al madinah yang arti harfiyahnya adalah kota. Dengan demikian, maka civil society diterjemahkan sebagai "masyarakat madani", yang mengandung tiga hal, yakni agama, peradaban dan perkotaan. Di sini, agama merupakan sumber, peradaban adalah prosesnya, dan masyarakat kota adalah hasilnya.

Sungguhpun begitu, di kalangan umat islam, bisa terjadi perbedaan interpretasi mengenai masyarakat madani ini. Perbedaan tersebut timbul dari perbedaan interpretasi tentang apa yang dimaksud dengan masyarakat unggul (al khair al ummah). la bisa diartikan sebagai masyarakat sipil, bisa pula negara. Tetapi jika kita kembali kepada pengertian masyarakat madani, yang merupakan pemikiran baru di zaman modern ini, maka masyarakat madani mencakup masyarakat sipil maupun negara. Masalahnya adalah mana yang dianggap primer dan mana yang sekunder.

Hingga sekarang ini, negara dipandang sebagai primer, walaupun dalam kenyata- annya, masyarakat sipil terlebih dahulu lahir sebelum terbentuknya negara RI. Perkembangan selanjutnya mengemukakan peranan negara secara menonjol sebagai agen perubahan. Negara mengalami proses idealisasi. Tetapi seperti dikatakan Gramsci, negara juga mempunyai peranan dalam pembinaan masyarakat. Di Indonesia, negara, secara tidak langsung ikut membentuk masyarakat sipil. Setidak-tidaknya, melalui negara telah mengangkat individu-individu untuk memasuki masyarakat ekonomi yang kompetitif. Sementara itu, tradisi gerakan kemasyaraliatan, agaknya tidak hilang begitu saja, bahkan mengalami revitalisasi. Organisasi-organisasi kemasyarakatan, merasa tidak cukup puas dengan peranan negara. Hal ini ikut menjelaskan gejala lahirnya LSM sebagai kekuatan pengimbang dan kekuatan yang memberdayakan masyarakat-masyarakat marjinal.

Di samping tampak menguatnya peranan negara, kita melihat pula perkembangan masyarakat sipil. Tapi kita juga melihat gejala ketiga, yakni pengintegrasian agama ke dalam negara, sebagai dampak dari pelaksanaan cita negara integralistik. Tendensi ini datang dari kedua belah pihak. $\mathrm{Di}$ satu pihak, agama tidak mau dan ingin menghindari konfrontasi dengan negara, dan jika bisa, memanfaatkan sumberdaya negara. Di lain pihak, negara tidak menghendaki timbulnya masyarakat sipil yang bisa merongrong legitimasi negara.

Namun kecenderungan untuk memanfaatkan negara ini bisa menimbulkan persaingan di antara agama-agama yang bisa menjadi potensi konflik. Apabila konflik berkembang, maka agama, sebagai salah satu jenis kepentingan golongan, bisa mengalami proses seperti yang diramalkan Hegel. Oleh sebab itu dialog antar agama merupakan kunci, sebagai pengganti persaingan dan konflik.

Agama-agama-bisa setuju dalam 
menginterpretasikan civil society sebagai masyarakat madani, yakni sebuah masyarakat etis dan masyarakat yang berbudaya. Dalam dialog tersebut, agama-agama perlu menemu-kenali apa yang disebut Hegel sebagai "kepentingan-kepentingan universal" umat manusia, dan memperjuangkannya secara bersama-sama. Jika pada tingkat masyarakat sipil, masalah ini dipecahkan, maka negara tidak perlu melakukan intervensi yang dampaknya bisa memarjinalisasikan masyarakat sipil.

\section{Penutup}

Agama di Indonesia, mengambil peranan penting dalam membentuk masyarakat sipil, khususnya sebagai masyarakat politik. Perkembangan masyarakat sipil ini ternyata lebih cepat dari pada perkembangan masyarakat ekonomi. Sebagai dampaknya, peranan negara lebih menonjol dan justru mengambil peran sebagai agen perubahan sosial yang berdampak terbentuknya masyarakat sipil, dari arti mencakup masyarakat politik maupun ekonomi.

Kecenderungan yang dominan di Indonesia adalah idealisasi negara, sebagai wadah nilai-nilai tertinggi. Perjuangan organisasi-organisasi keamanan ikut mendorong terbentuknya Negara-Ideal, atau Negara-Integralistik sebàgai kompromi dari kónflik antara sekularisme dan teokrasi. Dalam Negara-Ideal tersebut, agama dicegah untuk dominan dalam mewamai corak negara, tetapi diberi kesempatan untuk masuk dan membentuk nilai-nilai ideal itu ke dalam wadah negara.

Namun, kecenderungan idealistik dan integralistik bisa memarginalkan peranan agama. Marginalisasi agama berarti pengeringan sumber-sumber nilai. Karena itu nilai-nilai keagamaan perlu dikembangkan dengan memperkuat masyarakat sipil, sebagai benteng (bastion) kepentingan-kepentingan dan aspirasi masyarakat, termasuk masyarakat agama, yang kedudukannya cukup dominan dalam masyarakat Indonesia.

Tetapi pertarungan kepentingan-kepentingan sempit kelompok-kelompok agama bisa mengundang intervensi negara yang bisa berdampak marjinalisasi masyarakat sipil dan agama itu sendiri. Karena itu masyarakat sipil perlu terus menerus memelihara rasionalitasnya dan kemampuannya untuk bisa mengatur diri sendiri secara mandiri. Mengingat pentingnya agama-agama, para pemeluk agama-agama perlu melakukan dialog untuk menemukan kepentingan-kepentingan universal umat manusia dan sekaligus memelihara dan mengembangkan fungsi masyarakat sipil.

Guna menghilangkan kesalah pahaman berbagai pihak tentang masyarakat sipil, misalnya diartikan sebagai lawan dari pemerintahan militer atau sebagai masyarakat borjuis, maka yang dimaksud sebagai masyarakat sipil di sini adalah masyarakat madani, yakni sebuah masyarakat etis yang progresif menuju kepada terbentuknya peradaban yang unggul. 